\title{
Comparison of periodontal parameters among cardiovascular patients and healthy controls
}

\author{
Bateni E, DDS, MS ${ }^{1}$, Rabiei A, DDS, MS ${ }^{2}$, Sabzikari N, Dentistry Student ${ }^{3}$, Ghanbarzadegan \\ A, Dentistry Student ${ }^{4 *}$ \\ 1- Assistant Prof., Dept. of Periodontology, Rafsanjan University of Medical Sciences, Rafsanjan, Iran. 2- General Dentist, \\ Rafsanjan, Iran. 3- Dentistry Student, Student Research Committee, Urmia University of Medical Sciences, Urmia, Iran. 4- \\ Dentistry Student, Student Research Committee, Rafsanjan University of Medical Sciences, Rafsanjan, Iran; Dentistry \\ Student, Clinical Research Development Center, Ali ebn Abitaleb Hospital, Rafsanjan University of Medical Sciences, \\ Rafsanjan, Iran
}

\begin{abstract}
Received: November 2016, Accepted: February 2017

Background: This study was performed to evaluate periodontal status in patients with cardiovascular disease (CVD) and assessment of periodontal diseases prevalence in these patients.

Materials and Methods: In this cross-sectional study, data on 100 patients were collected with mean age of $51 \pm 11$ years. The case group included of 50 patients with confirmed CVD who referred to Ali-ibn Abi Talib hospital of Rafsanjan, Iran. Control group included 50 healthy volunteer subjects with no history of systemic diseases that referred to oral medicine diagnosis department of Rafsanjan Dental School. Plaque index, bleeding point index, clinical attachment loss, pocket depth and number of loosed teeth were assessed in this study.

Results: Plaque index, clinical attachment loss, pocket depth and number of lost teeth in the target group were more than the control group $(\mathrm{P}<0.05)$. There was no significant difference in bleeding point index between the two groups.

Conclusions: Patients who suffer from CVD had a higher risk for periodontal disease. So oral health instructions for this group of patients should be considered more.
\end{abstract}

Keywords: Cardiovascular Diseases, Periodontal Indices, Risk Factors, Periodontitis, Cardiac Disease

\section{Introduction}

Periodontitis is one of the most common infectious diseases that can cause progressive destruction of periodontal ligaments and alveolar bone. Gingivitis is an inflammatory condition limited to gingival tissues. These two diseases are mostly caused by toxic products of subgingival plaque. Also the host response to bacterial plaque and its products could be destructive too $(1,2)$.

Many epidemiological studies have found statistically meaningful association between established periodontitis and cardiovascular disease (CVD) (3-5).

There are some theories justifying the relationship between periodontal diseases and CVD (6-8). Some of these theories rely on common risk factors of these two types of diseases (9), while others point to direct systemic effects of periodontal diseases (1012).

Although, several studies in other countries have claimed relationship between CVD and periodontal diseases (13-16), American Heart Association (AHA) claims that periodontal disease is associated with atherosclerosis but further concludes that there is no evidence for such relation, possibly due to several research gaps (17). Other comprehensive researches show an association between periodontitis and CVD, but they also say more research should

\footnotetext{
* Corresponding author: Arash Ghanbarzadegan, Student Research Committee, Rafsanjan University of Medical Sciences, Rafsanjan, Iran.

E-mail: Arash.Ghanbarzadegan@yahoo.com
} 
be conducted to make better evidences (18, 19), and also not enough studies have succeeded to show that CVD may increase the risk of periodontal complications (20). Effects of smoking, high blood pressure and high amount of blood lipids on CVD have been proved. But, these factors do not show all epidemiologic and clinical symptoms of CVD $(5,21)$.

The present study was performed to evaluate periodontal status in patients who suffer from CVD in comparison with healthy individuals. Relationship between periodontal status of patients with CVD and their body mass index (BMI), blood cholesterol levels and blood pressure were determined.

Moreover, indices including clinical attachment loss, probing pocket depth, plaque index and number of lost teeth were assessed in each individual.

\section{Materials and Methods}

In this descriptive cross-sectional study, the target group comprised of 50 patients with CVD who referred to Ali-ibn Abi Talib hospital of Rafsanjan, Iran, and their CVD was confirmed by one particular cardiologist. Our control group also consisted of 50 healthy volunteers with no systemic diseases or any other medical conditions who referred to oral and maxillofacial medicine department of Rafsanjan Dental School.

Individuals were excluded from study if they had any recent (in the last 3 months) history of using antibiotics (such as tetracycline), drugs with gingival enlargement effects (cyclosporine, phenytoin and $\mathrm{Ca}^{2+}$ channel blockers), anti-inflammatory or anti-epileptic drugs. Other exclusion criteria were any known history of systemic diseases (except CVD), pregnancy, any history of periodontal treatment in last 6 months, any need to antibiotic prophylaxis and having less than 15 teeth totally.

This study was approved by Ethics Committee of Rafsanjan University of Medical Sciences. Patients were informed about the research protocol and after getting written informed consent, they underwent comprehensive clinical examinations including determination of plaque index (PI), bleeding point index (BPI), clinical attachment loss (CAL) and periodontal pocket depth (PPD).

These evaluations were performed by a trained dentistry student. Determination of dental plaque was done on the basis of Sillness and Loe method (22), in four line angels of each tooth (mesiobuccal, mesiolingual, distobuccal and distolingual). This index was determined as a percentage: (points with plaque/number of teeth $\times 4) \times 100$.

CAL was measured from Cemento enamel junction (CEJ) to the bottom of gingival pocket using a calibrated coded Williams periodontal probe No. 14 (Delab, Treffurt, Germany).

Pocket depth was calculated for two quadrants (one maxillary, one mandibular) in 6 random points (mesiobuccal, midbuccal, distobuccal, mesiolingual, midlingual and distolingual) from gingival margin to the bottom of pocket. Periodontal probes were used with gentle pressure during all examinations.

Bleeding on probing was observed and recorded by touching sulcus wall or periodontal pocket in the 6 points mentioned above (22). This index was also reported as a percentage (number of bleeding points/number of teeth $\times 4) \times 100$.

BMI was determined for each participant $\left(\mathrm{kg} / \mathrm{m}^{2}\right)$. Cholesterol level $(\mathrm{mg} / \mathrm{dl})$ and blood pressure $(\mathrm{mmHg})$ of each participant were measured by their test sheet and by an experienced cardiology department nurse.

Statistical analyses were performed using SPSS (version 21.0, IBM Corporation, Armonk, NY, USA). Results were reported as "mean \pm standard deviation" for quantitative variables and as "percentage" for qualitative variants. Independent two-sample Student's ttest was used in analyzing and comparing the periodontal parameters between patients and healthy participants, and between men and women. 
Chi-square test was used to compare qualitative parameters between evaluated groups. Associations between periodontal parameters and qualitative variables in cardiac patients were evaluated using the Spearman rank order correlation coefficient. The significance level of the test (P-value) was considered 0.05 .

\section{Results}

This study consisted of a target group with CVD (27 men, 23 women and group mean age of $54.5 \pm 9.71$ years), and a control group of healthy individual (18 men, 32 women and group mean age of $51.5 \pm 10.4$ years).
There were no significant differences in education and socioeconomic levels and the number of smokers between the two groups. Other comparison of quantitative variables among the target group and control group is shown in table 1 .

Bleeding point index between two groups was similar. Apart from BPI, there were significant differences in other parameters among the two groups (table 1). Mean cholesterol reported by patients test sheets was $182.1 \pm 35$ for men, and $199.2 \pm 8.22$ for women, and this item did not have any significant difference between the two gender $(\mathrm{P}=0.152)$

Table 1: Comparison of quantitative variables among the target group and control group

\begin{tabular}{cccc}
\hline & $\begin{array}{c}\text { Patients with CVD } \\
(\mathbf{n}=\mathbf{5 0})\end{array}$ & $\begin{array}{c}\text { Healthy subjects } \\
(\mathbf{n}=\mathbf{5 0})\end{array}$ & P \\
\hline Age (years) & $54.5 \pm 9.71$ & $51.5 \pm 10.4$ & 0.130 \\
Height (cm) & $167.6 \pm 8.92$ & $166.2 \pm 10$ & 0.470 \\
Weight (kg) & $73.2 \pm 13.3$ & $65.2 \pm 12.2$ & $* 0.003$ \\
BMI (kg/m $)$ & $26 \pm 4.09$ & $23.7 \pm 4.59$ & $* 0.010$ \\
BPI (\%) & $35.8 \pm 24.4$ & $35.4 \pm 16.2$ & 0.930 \\
CAL (mm) & $4.10 \pm 1.50$ & $1.85 \pm 1.92$ & $*<0.001$ \\
PPD (mm) & $2.26 \pm 0.70$ & $1.86 \pm 0.53$ & $* 0.002$ \\
PI (\%) & $87.3 \pm 17.6$ & $76.5 \pm 20.6$ & $* 0.006$ \\
NLT & $8.54 \pm 3.66$ & $3.88 \pm 4.09$ & $*<0.001$ \\
\hline
\end{tabular}

Test type: independent two-sample Student's t-test

CVD: Cardiovascular disease; BMI: Body mass index; BPI: Bleeding point index;

CAL: Clinical attachment loss; PPD: Periodontal pocket depth; PI: Plaque index;

NLT: Number of lost teeth

*Significant difference: $\mathrm{P}<0.05$

As mentioned in table 2, the sex distribution and the measured quadrant frequency distribution did not present any meaningful differences among the two groups $(\mathrm{P}=0.161)$. The mean height and weight of men were higher than women in patients group $(\mathrm{P}<$ 0.001 and $\mathrm{P}=0.010$, respectively). Other characteristics did not present any significant differences among male and female.

Table 2: Comparison of distribution of qualitative variables in the two study groups

\begin{tabular}{cccc}
\hline & Patient with CVD $(\mathbf{n}=\mathbf{5 0})$ & Control group $(\mathbf{n}=\mathbf{5 0})$ & P \\
\hline Sex & $23(46)$ & $32(64)$ & \\
Female & $27(54)$ & $18(36)$ & 0.070 \\
Male & $30(60)$ & $23(46)$ & 0.161 \\
Quadrant & $20(40)$ & $27(54)$ & \\
$\mathbf{1}$ and 3 & 2 and 4 & &
\end{tabular}

CVD: Cardiovascular disease

Test type: chi-square test, Significant difference: $\mathrm{P}<0.05$ 
Table 3 demonstrates significant differences between findings documented in our study by using Pearson's correlation coefficient. It shows the association among qualitative variables. In the case of a positive result (also statistically meaningful), demonstrates a direct relationship among the variables and in the case of negative result (also statistically meaningful), demonstrates a reverse association among the variables.

Table 3: Association of quantitative variables associated in patients with CVD

\begin{tabular}{|c|c|c|c|c|c|c|c|c|c|c|c|c|}
\hline & age & $\begin{array}{l}\text { Duratio } \\
\text { n of } \\
\text { illness }\end{array}$ & Height & Weight & BMI & SBP & DBP & $\begin{array}{l}\text { Chole } \\
\text { sterol }\end{array}$ & BPI & CAL & PPD & PI \\
\hline $\begin{array}{l}\text { Duration } \\
\text { of illness } \\
\text { (months) }\end{array}$ & $\begin{array}{l}r=0.082 \\
P=0.569\end{array}$ & - & & & & & & & & & & \\
\hline $\begin{array}{l}\text { Height } \\
(\mathrm{cm})\end{array}$ & $\begin{array}{l}r=-0.054 \\
P=0.708\end{array}$ & $\begin{array}{l}\mathrm{r}=0.079 \\
\mathrm{P}=0.585\end{array}$ & - & & & & & & & & & \\
\hline $\begin{array}{l}\text { Weight } \\
(\mathrm{kg})\end{array}$ & $\begin{aligned} \mathrm{r} & =0.155 \\
\mathrm{P} & =0.282\end{aligned}$ & $\begin{array}{l}r=-0.016 \\
P=0.911\end{array}$ & $\begin{array}{c}r=0.583 \\
\mathrm{P}<0.001\end{array}$ & - & & & & & & & & \\
\hline $\begin{array}{c}\text { BMI } \\
(\mathrm{Kg} / \mathrm{m} 2)\end{array}$ & $\begin{array}{l}\mathrm{r}=0.225 \\
\mathrm{P}=0.117\end{array}$ & $\begin{array}{l}r=-0.071 \\
P=0.625\end{array}$ & $\begin{array}{l}\mathrm{r}=0.026 \\
\mathrm{P}=0.859\end{array}$ & $\begin{array}{l}\mathrm{r}=0.824 \\
\mathrm{P}<0.001\end{array}$ & - & & & & & & & \\
\hline $\begin{array}{c}\text { SBP } \\
(\mathrm{mmHg})\end{array}$ & $\begin{array}{l}\mathrm{r}=0.292 \\
\mathrm{P}=0.040\end{array}$ & $\begin{array}{l}r=-0.106 \\
P=0.463\end{array}$ & $\begin{array}{l}\mathrm{r}=0.033 \\
\mathrm{P}=0.818\end{array}$ & $\begin{array}{l}\mathrm{r}=0.015 \\
\mathrm{P}=0.919\end{array}$ & $\begin{array}{l}\mathrm{r}=-0.011 \\
\mathrm{P}=0.938\end{array}$ & - & & & & & & \\
\hline $\begin{array}{c}\text { DBP } \\
(\mathrm{mmHg})\end{array}$ & $\begin{array}{l}\mathrm{r}=0.318 \\
\mathrm{P}=0.024\end{array}$ & $\begin{array}{l}r=-0.183 \\
P=0.204\end{array}$ & $\begin{array}{l}r=0.103 \\
\mathrm{P}=0.478\end{array}$ & $\begin{array}{l}r=0.145 \\
P=0.316\end{array}$ & $\begin{array}{l}r=0.099 \\
\mathrm{P}=0.494\end{array}$ & $\begin{array}{l}\mathrm{r}=0.586 \\
\mathrm{P}<0.001\end{array}$ & - & & & & & \\
\hline $\begin{array}{c}\text { Cholester } \\
\text { ol } \\
(\mathrm{mg} / \mathrm{dl})\end{array}$ & $\begin{array}{l}\mathrm{r}=0.124 \\
\mathrm{P}=0.392\end{array}$ & $\begin{array}{l}r=-0.227 \\
P=0.113\end{array}$ & $\begin{array}{l}r=-0.102 \\
P=0.480\end{array}$ & $\begin{array}{l}r=-0.060 \\
P=0 / 681\end{array}$ & $\begin{array}{l}r=-0.022 \\
P=0.879\end{array}$ & $\begin{array}{l}r=0.339 \\
P=0.016\end{array}$ & $\begin{array}{l}\mathrm{r}=0.351 \\
\mathrm{P}=0.013\end{array}$ & - & & & & \\
\hline BPI (\%) & $\begin{array}{l}\mathrm{r}=0.190 \\
\mathrm{P}=0.187\end{array}$ & $\begin{array}{l}\mathrm{r}=0.079 \\
\mathrm{P}=0.586\end{array}$ & $\begin{array}{l}r=0 / 061 \\
P=0 / 672\end{array}$ & $\begin{array}{l}\mathrm{r}=0.123 \\
\mathrm{P}=0.394\end{array}$ & $\begin{array}{l}\mathrm{r}=0.127 \\
\mathrm{P}=0.381\end{array}$ & $\begin{array}{l}\mathrm{r}=0.232 \\
\mathrm{P}=0.105\end{array}$ & $\begin{array}{l}\mathrm{r}=0.228 \\
\mathrm{P}=0.111\end{array}$ & $\begin{array}{l}\mathrm{r}=-0.127 \\
\mathrm{P}=0.381\end{array}$ & - & & & \\
\hline $\begin{array}{l}\text { CAL } \\
(\mathrm{mm})\end{array}$ & $\begin{array}{l}r=0.247 \\
P=0.083\end{array}$ & $\begin{array}{l}r=-0.036 \\
P=0.805\end{array}$ & $\begin{array}{l}r=-0.157 \\
P=0.277\end{array}$ & $\begin{array}{l}r=-0.081 \\
P=0.575\end{array}$ & $\begin{array}{l}\mathrm{r}=0.010 \\
\mathrm{P}=0.944\end{array}$ & $\begin{array}{l}\mathrm{r}=0.287 \\
\mathrm{P}=0.043\end{array}$ & $\begin{array}{l}\mathrm{r}=0.336 \\
\mathrm{P}=0.017\end{array}$ & $\begin{array}{l}\mathrm{r}=0.143 \\
\mathrm{P}=0.323\end{array}$ & $\begin{array}{l}\mathrm{r}=0.397 \\
\mathrm{P}=0.004\end{array}$ & - & & \\
\hline $\mathrm{PPD}(\mathrm{mm})$ & $\begin{array}{l}\mathrm{r}=0.197 \\
\mathrm{P}=0.170\end{array}$ & $\begin{array}{c}r=0.605 \\
\mathrm{P}=0.655\end{array}$ & $\begin{array}{l}\mathrm{r}=0.097 \\
\mathrm{P}=0.503\end{array}$ & $\begin{array}{l}\mathrm{r}=0.042 \\
\mathrm{P}=0.774\end{array}$ & $\begin{array}{l}\mathrm{r}=-0.013 \\
\mathrm{P}=0.931\end{array}$ & $\begin{array}{l}\mathrm{r}=0.151 \\
\mathrm{P}=0.295\end{array}$ & $\begin{array}{l}\mathrm{r}=0.218 \\
\mathrm{P}=0.129\end{array}$ & $\begin{array}{l}\mathrm{r}=0.098 \\
\mathrm{P}=0.496\end{array}$ & $\begin{array}{l}\mathrm{r}=0.681 \\
\mathrm{P}<0.001\end{array}$ & $\begin{array}{l}\mathrm{r}=0.625 \\
\mathrm{P}<0.001\end{array}$ & - & \\
\hline PI (\%) & $\begin{array}{l}\mathrm{r}=0.310 \\
\mathrm{P}=0.028\end{array}$ & $\begin{array}{l}\mathrm{r}=0.153 \\
\mathrm{P}=0.288\end{array}$ & $\begin{array}{l}\mathrm{r}=0.284 \\
\mathrm{P}=0.045\end{array}$ & $\begin{array}{l}\mathrm{r}=0.419 \\
\mathrm{P}=0.002\end{array}$ & $\begin{array}{l}\mathrm{r}=0.333 \\
\mathrm{P}=0.018\end{array}$ & $\begin{array}{l}\mathrm{r}=0.209 \\
\mathrm{P}=0.145\end{array}$ & $\begin{array}{l}\mathrm{r}=0.146 \\
\mathrm{P}=0.310\end{array}$ & $\begin{array}{l}\mathrm{r}=0.080 \\
\mathrm{P}=0.579\end{array}$ & $\begin{array}{l}\mathrm{r}=0.287 \\
\mathrm{P}=0.044\end{array}$ & $\begin{array}{l}r=-0.014 \\
P=0.921\end{array}$ & $\begin{array}{l}\mathrm{r}=0.142 \\
\mathrm{P}=0.324\end{array}$ & - \\
\hline NLT & $\begin{array}{l}\mathrm{r}=0.082 \\
\mathrm{P}=0.571\end{array}$ & $\begin{array}{l}r=0.034 \\
P=0.813\end{array}$ & $\begin{array}{l}r=0.041 \\
P=0.780\end{array}$ & $\begin{array}{l}r=0.076 \\
\mathrm{P}=0.601\end{array}$ & $\begin{array}{l}r=0.075 \\
P=0.603\end{array}$ & $\begin{array}{l}r=0.120 \\
P=0.408\end{array}$ & $\begin{array}{l}\mathrm{r}=0.208 \\
\mathrm{P}=0.147\end{array}$ & $\begin{array}{l}r=0.072 \\
P=0.620\end{array}$ & $\begin{array}{l}\mathrm{r}=0.054 \\
\mathrm{P}=0.709\end{array}$ & $\begin{array}{l}r=0.090 \\
P=0.534\end{array}$ & $\begin{array}{c}r=-0.049 \\
P=0.732\end{array}$ & $\begin{array}{l}\mathrm{r}=0.259 \\
\mathrm{P}=0.069\end{array}$ \\
\hline
\end{tabular}

CVD: Cardiovascular disease; BMI: Body mass index; SBP: Systolic blood pressure; DBP: Diastolic blood pressure; BPI: Bleeding point index; CAL: Clinical attachment loss; PPD: Periodontal pocket depth; PI: Plaque index; NLT: Number of lost teeth Significant difference: $\mathrm{P}<0.05$, significant differences are shown with colorful cells in the table.

\section{Discussion}

The aim of this study was to evaluate periodontal status in patients with CVD and compare them with healthy individuals.

In recent decades, some studies have been done on the relationship between systemic and periodontal diseases (23). Some of these studies were done specifically on the relationship between cardiac and periodontal diseases and reporting a significant correlation between them $(4,24-26)$.
Although it is believed that controlling the periodontal inflammatory conditions has a positive effect on the health of patients with CVD, there are not enough evidences to show that cardiac disease can increase the risk of periodontal problems $(18,19)$.

Like other studies (27-29) we found that patients with CVD had worse periodontal status than control group. In other words, PI, CAL and tooth loss in these patients were more than control group. Average PI was significantly higher in the patient group. It 
may be due to poor oral hygiene in these patients in comparison with the healthy individuals.

Unlike other studies, difference in BOP between the two groups was not significant. This contradiction may be due to the differences in the population of different studies (30).

Also in patients with CVD, there was a significant relation between CAL, systolic and diastolic blood pressure and BOP index.

We also found a significant positive association between plaque index, height, weight, BMI and BPI. So that, as these indicators were more, PI was also higher.

Unlike previous studies $(30,31)$, number of tooth lost was significantly higher in the patient group. This finding most likely reflects different lifestyle and poor oral hygiene in the patient group. PPD in the patient group was significantly higher than control group.

\section{Conclusion}

According to our findings it seems that PI, CAL, PPD and tooth loss are higher in the patients with CVD in comparison with healthy subjects. So it can be concluded that overall periodontal status is worsen in patients with CVD. In addition, a better oral health instruction for patients with CVD is necessary. It is suggested to have more systematic reviews on articles to cover the different research gaps.

\section{Acknowledgement}

We should thank all the participants in this study. The authors did not have any conflict of interest. This study was under the funds of Rafsanjan University of Medical Sciences.

The results were presented at $15^{\text {th }}$ international congress of Iranian Academy of Periodontology.

Conflict of interests: None declared.

\section{References}

1. Scannapieco FA. Position paper of The American Academy of Periodontology: periodontal disease as a potential risk factor for systemic diseases. J Periodontol 1998; 69(7):841-50.

2. Dorn JM, Genco RJ, Grossi SG, Falkner KL, Hovey KM, Iacoviello L, et al. Periodontal disease and recurrent cardiovascular events in survivors of myocardial infarction (MI): the Western New York Acute MI Study. J Periodontol 2009; 81(4):502-11.

3. Imaki M, Ogawa Y, Yoshida Y, Uchida M, Tanada S. Cohort study of the total leukocyte count and periodontal disease among company employees. Environ Health and Prev Med 1999; 4(1):54-7.

4. Khosravi Samani M, Jalali F, Seyyed Ahadi SM, Hoseini SR, Dabbagh Sattari F. The relationship between acute myocardial infarction and periodontitis. Caspian J Intern Med 2013;4(2):667-71.

5. Buhlin K, Gustafsson A, Pockley AG, Frostegård J, Klinge B. Risk factors for cardiovascular disease in patients with periodontitis. Eur Heart J 2003; 24(23):2099107.

6. Joshipura KJ, Rimm EB, Douglass CW, Trichopoulos D, Ascherio A, Willett WC. Poor oral health and coronary heart disease. J Dent Res 1996; 75(9):1631-6.

7. Cabala A, Chomyszyn-Gajewska M, Drozdz W. The impact of periodontal infection on systemic inflammatory process and atherosclerosis. Przegl lek 2006; 63(8):681-4.

8. Ford PJ, Yamazaki K, Seymour GJ. Cardiovascular and oral disease interactions: what is the evidence? Prim Dent Care 2007; 14(2):59-66.

9. Herzberg MC, Meyer MW. Effects of oral flora on platelets: possible consequences in cardiovascular disease. J Periodontol 1996; 67(10 Suppl):1138-42.

10. Accarini R, de Godoy MF. Doença periodontal como potencial fator de risco para síndromes coronarianas agudas. Arq Bras Cardiol 2006; 87(5):592-6.

11. Johnson RC, Leopold JA, Loscalzo J. Vascular calcification: pathobiological mechanisms and clinical implications. Circ Res 2006; 99(10):1044-59.

12. Johnson GK, Hill M. Cigarette smoking and the periodontal patient. J Periodontol 2004; 75(2):196-209.

13. Zanella SM, de Souza LV, Suzigan BH, SabaChujfi E, Barbisan JN. Associação entre saúde bucal e doença arterial coronária aterosclerótica em pacientes submetidos a 
cineangiocoronariografia: estudo transversal controlado. Revista Brasileira de Cardiologia Invasiva 2012; 20(2):178-83.

14. Dhadse P, Gattani D, Mishra R. The link between periodontal disease and cardiovascular disease: How far we have come in last two decades? J Indian Soc Periodontol 2010; 14(3):148-54.

15. Shetty D, Dua M, Kumar K, Dhanapal R, Astekar M, Shetty DC. Oral hygiene status of individuals with cardiovascular diseases and associated risk factors. Clin Pract 2012; 2(4):e86. doi: 10.4081/cp.2012.e86.

16. Ramesh A, Thomas B, Rao A. Evaluation of the association between chronic periodontitis and acute coronary syndrome: A case control study. J Indian Soc Periodontol 2013; 17(2):210-3.

17. Lockhart PB, Bolger AF, Papapanou PN, Osinbowale O, Trevisan M, Levison ME, et al. Periodontal disease and atherosclerotic vascular disease: does the evidence support an independent association?: a scientific statement from the American Heart Association. Circulation 2012; 125(20):2520-44.

18. Stewart R, West M. Increasing evidence for an association between periodontitis and cardiovascular disease. Circulation 2016; 133(6):549-51.

19. Kjellström B, Rydén L, Klinge B, Norhammar A. Periodontal disease - important to consider in cardiovascular disease prevention. Expert Rev Cardiovasc Ther 2016; 14(9):987-9.

20. Blaizot A, Vergnes JN, Nuwwareh S, Amar J, Sixou M. Periodontal diseases and cardiovascular events: meta-analysis of observational studies. Int Dent J 2009; 59(4):197-209.

21. Watt RG, Tsakos G, de Oliveira C, Hamer M. Tooth loss and cardiovascular disease mortality risk--results from the Scottish Health Survey. PLoS One 2012; 7(2):e30797. doi: 10.1371/journal.pone.0030797

22. Carranza FA, Newman MG, Irving Glickman's Clinical Periodontology Glickman. Clinical periodontology. $8^{\text {th }}$ ed. Philadelphia, United States: Walter Burns Saunders Co; 1996. P.6177.

23. Matthews DC. Periodontal medicine: a new paradigm. J Can Dent Assoc 2000; 66(9):48891.

24. Zhang B, Khalaf H, Sirsjo A, Bengtsson T. Gingipains from the periodontal pathogen porphyromonas gingivalis play a significant role in regulation of angiopoietin 1 and angiopoietin 2 in human aortic smooth muscle cells. Infect Immun 2015; 83(11):4256-65.

25. Noguchi S, Toyokawa S, Miyoshi Y, Suyama Y, Inoue K, Kobayashi Y. Five-year follow-up study of the association between periodontal disease and myocardial infarction among Japanese male workers: MY Health Up Study. J Public Health (Oxf) 2015; 37(4):605-11.

26. Persson GR, Persson RE. Cardiovascular disease and periodontitis: an update on the associations and risk. J Clin Periodontol 2008; 35(8 Suppl):362-79.

27. Gomes Domingues JE, Vettore MV, Lima E. Association between markers of cardiovascular risk and clinical parameters of periodontitis. Rev Odontol UNESP 2013; 42(5):336-43.

28. Geerts SO, Legrand V, Charpentier J, Albert A, Rompen EH. Further evidence of the association between periodontal conditions and coronary artery disease. J Periodontol 2004; 75(9):1274-80.

29. Briggs JE, McKeown PP, Crawford VLS, Woodside JV, Stout RW, Evans A, et al. Angiographically confirmed coronary heart disease and periodontal disease in middle-aged males. J Periodontol 2006; 77(1):95-102.

30. Lopez R, Oyarzun M, Naranjo C, Cumsille F, Ortiz M, Baelum V. Coronary heart disease and periodontitis -- a case control study in Chilean adults. J Clin Periodontol 2002; 29(5):468-73.

31. Geismar K, Stoltze K, Sigurd B, Gyntelberg F, Holmstrup P. Periodontal disease and coronary heart disease. J Periodontol 2006; 77(9):154754 . 